NBER WORKING PAPER SERIES

\title{
THE EFFECT OF AUTOMOBILE INSURANCE AND ACCIDENT LIABILITY LAWS ON TRAFFIC FATALITIES
}

\author{
Alma Cohen \\ Rajeev Dehejia \\ Working Paper 9602 \\ http://www.nber.org/papers/w9602 \\ NATIONAL BUREAU OF ECONOMIC RESEARCH \\ 1050 Massachusetts Avenue \\ Cambridge, MA 02138 \\ April 2003
}

We are grateful to Kenneth Abraham, Orley Ashenfelter, Lucian Bebchuk, Liran Einav, Amy Finkelstein, Michael Greenstone, Sam Peltzman, Jack Porter, Steven Shavell, and participants at the Harvard labor economics seminar for their valuable suggestions. We are also grateful to Richard Derrig for helping us with some of the data. All remaining errors are our own. Cohen thanks the NBER Postdoctoral Fellowship in Aging and Health Economics for financial support. Dehejia thanks the NBER and the Industrial Relations Section, Princeton University, for their kind hospitality while working on this project. The views expressed herein are those of the authors and not necessarily those of the National Bureau of Economic Research.

C2003 by Alma Cohen and Rajeev Dehejia. All rights reserved. Short sections of text not to exceed two paragraphs, may be quoted without explicit permission provided that full credit including Cnotice, is given to the source. 
The Effect of Automobile Insurance and Accident Liability Laws on Traffic Fatalities Alma Cohen and Rajeev Dehejia

NBER Working Paper No. 9602

April 2003

JEL No. G22, J28, K13

\begin{abstract}
This paper investigates the incentive effects of automobile insurance, compulsory insurance laws, and no-fault liability laws on driver behavior and traffic fatalities. We analyze a panel of 50 U.S. states and the District of Columbia from 1970-1998, a period in which many states adopted compulsory insurance regulations and/or no-fault laws. Using an instrumental variables approach, we find evidence that automobile insurance has moral hazard costs, leading to an increase in traffic fatalities. We also find that reductions in accident liability produced by no-fault liability laws have led to an increase in traffic fatalities (estimated to be on the order of 6\%). Overall, our results indicate that, whatever other benefits they might produce, increases in the incidence of automobile insurance and moves to no-fault liability systems have significant negative effects on traffic fatalities.
\end{abstract}

Alma Cohen

National Bureau of Economic Research

1050 Massachusetts Avenue

Cambridge, MA 02138

alcohen@nber.org
Rajeev Dehejia

Department of Economics and SIPA

Columbia University

New York, NY 10027

and NBER

rd247@columbia.edu 
In the United States today, we are at the threshold of a great experiment in social insurance - one of the most far-reaching in consequence of any that has been yet attempted in the New World. Probably within the next decade or two, most of the states will pass laws, the purposes of which will be the financial assistance of some or all of the victims of automobile accidents, and the prevention of such accidents in so far as is possible.

--Edison L. Bowers, Selected Articles on Compulsory

Automobile Insurance. New York: The W.H. Wilson Company, 1929.

\section{Introduction}

This paper examines how economic incentives and liability regulation influence driver behavior and, in turn, traffic fatalities. We use the introduction of compulsory insurance and no-fault liability regulation to examine the moral hazard effects of automobile insurance, compulsory insurance laws, and no-fault liability laws. We analyze a panel of 50 U.S. states and the District of Columbia from 1970-1998, a period in which many states adopted compulsory insurance regulations and/or no-fault laws. Using compulsory insurance as an instrument for the proportion of uninsured motorists, we find that automobile insurance has significant moral hazard costs, namely reducing precautions and increasing traffic fatalities. We also find that limiting motor vehicle liability through no-fault liability laws leads to an increase in traffic fatalities. Overall our results indicate that, whatever benefits flow from increasing the incidence of automobile insurance and from moves to a no-fault system, there are also significant moral hazard costs to doing so.

Traffic accidents have very large costs which merit substantial attention by economists (see, e.g., Edlin (1999), Levitt and Porter (2001)). These accidents claim over 40,000 lives each year in the United States, roughly the same as the number of Americans killed during the Vietnam War. Americans spend roughly $\$ 100$ billion each year on automobile insurance premia, and they bear over $\$ 250$ billion in uninsured accident costs each year. The incidence of motor vehicle crashes and traffic fatalities is likely to be influenced significantly by choices made by drivers (including whether to use seat belts or air bags, how carefully to drive, whether to drink alcohol, and how much to drive). Accordingly, economists have long been interested in how these choices are influenced by agents' 
economic incentives and by various legal rules and policy measures (see, e.g., the seminal work of Peltzman (1975a,b)).

Beginning in 1970, most U.S. states adopted compulsory automobile insurance requirements. Over the same period, 16 states adopted no-fault automobile insurance. The impact of these policy shifts on traffic fatalities is of interest for two reasons. First, identifying this effect - which we shall see is significant - is necessary for assessing the social desirability of these policies. Second, these changes in automobile insurance regulations provide a large-scale natural experiment through which we can examine the moral hazard effects of automobile insurance and the incentive effects of liability exposure. In this sense, the changes in laws that we examine offer an interesting window on a larger set of phenomena.

Specifically, we investigate two related issues. First, we examine whether having automobile insurance has a moral-hazard effect on traffic fatalities; empirically, we examine the proportion of uninsured motorists. As a theoretical matter, insurance does have the moral hazard cost of reducing the policyholder's incentives to take precautions against the insured loss. ${ }^{1}$ This is also theoretically the case for the particular type of insurance that we examine, namely insurance for automobile accidents (see Shavell (1982, 1987, and 2000)). However, the question is whether the reduction in precautions against automobile accidents produced by automobile insurance - which theory predicts - is empirically significant. For example, it might be that drivers' concern for their own safety and health provide sufficient incentives for them to take precautions (to the extent that taking precautions is affected at all by incentives) and that the presence of insurance makes little difference on the margin. Although there has been much interest in the incidence of automobile insurance and uninsured motorists, ${ }^{2}$ whether automobile insurance leads to moral hazard costs is an open question that has not been addressed by existing research.

\footnotetext{
${ }^{1}$ Classic references analyzing this effect include Pauly (1968), Spence and Zeckhauser (1971) and Shavell (1979). For a comprehensive recent survey of models investigating the moral hazard costs of insurance, see Winter (2000).

${ }^{2}$ Edlin (1999) documents the congestion externalities of driving, but these are distinct from the moral hazard costs of insurance.
} 
Our strategy for examining this issue is to look at the consequences of a natural experiment: the adoption of compulsory insurance regulations in some states governed by tort law. Because this change produces a reduction in uninsured motorists not attributable to other confounding factors, we are able to test the consequences of a reduction in uninsured motorists on traffic fatalities. Although some work on compulsory insurance has been done (see Ma and Schmidt (2000) and Cole, Dumm, and McCullough (2001)), none of these papers make the connection between such regulations and traffic fatalities. Derrig et al. (2001), who do connect the two, find insignificant effects on fatalities rates. Our results indicate that a reduction in the incidence of uninsured motorists produces an increase in traffic fatalities.

The second issue we examine is the effect on traffic fatalities of the reduction in liability brought about by no-fault laws. Earlier work by Landes (1982) suggested that, by reducing incentives to drive carefully, such laws have led to an increase in traffic fatalities in the United States. Subsequently, Zador and Lund (1986) re-ran Landes's regressions using a longer data set and found the opposite effect; Kochanowski and Young (1985) and Derrig et al (2001) found no significant effect; and Cummins, Phillips, and Weiss (2001) recently found a significant positive effect of no-fault on traffic fatalities. ${ }^{3}$ However, all states that adopted no-fault limitations on liability also adopted compulsory insurance requirements at the same time, and these earlier studies did not attempt to separate the effects of the two elements of the legislation. Thus, they did not isolate the effect of limitations on liability as distinct from the effects of the accompanying adoption of compulsory insurance requirements. We consider the two elements of legislation simultaneously, and in this way are able to identify the effect of no-fault limitations on liability separately from the effect of compulsory insurance requirements. We find that no-fault limitations on liability do increase fatalities. Specifically, we estimate that the effect of such limitations is to increase fatalities by about $6 \%$.

This paper is also related to, and seeks to contribute to, the broader literature on the factors and policy measures that influence traffic fatalities. There is an extensive literature on 
how the use of seat belts directly reduces fatalities and on whether it indirectly increases fatalities by encouraging users to drive less carefully (see, e.g., Peltzman (1975a), Levitt and Porter (1999), Cohen and Einav (2001)). There is also work on how traffic fatalities are influenced by the consumption of alcohol, and in turn by some measures discouraging the sale of alcohol (see, e.g., Levitt and Porter (2001), Sloan, Reilly, and Schenzler (1994)). White (1989) investigates how comparative and contributory negligence rules affect the levels of care used by drivers (as judged by jury determination in accident cases). Vickery (1968), Edlin (1999) and Edlin and Mandic (1999) examine the effects of miles driven on fatalities and how they could be influenced by appropriately designed taxes or insurance premia.

This paper is organized as follows. Section 2 provides the necessary background by discussing the laws regarding compulsory insurance and no-fault liability. Section 3 lays out theoretical predictions and our approach to testing them. Section 4 describes the data. Section 5 presents our results. Section 6 makes concluding remarks.

\section{Automobile Insurance and Liability for Accidents}

We start with some background on automobile insurance and liability. There is a wide range of regulation governing automobile insurance and liability. In this paper, we focus on two aspects of regulation that directly affect drivers: compulsory insurance and no-fault systems.

\subsection{Compulsory Insurance Regulation}

Each year a large amount of insurance coverage for automobile accidents is purchased in the US. Total automobile liability insurance premia are over $\$ 100$ billion annually. A significant amount of insurance would be bought without any regulation, simply because drivers are risk-averse. However, current purchases might be influenced by the existence of compulsory insurance regulations.

Compulsory automobile insurance means that all those operating a motor vehicle must purchase insurance. Given the bounded nature of assets that individuals commonly

\footnotetext{
${ }^{3}$ In studies on other countries, Devlin (1992) and McEwin (1989) found that no-fault liability laws increased
} 
have, it is often rational for them to elect not to purchase insurance if they are free to do so (e.g., Huberman, Mayers and Smith (1993)). Compulsory insurance laws ensure some compensation to those injured in automobile accidents (see Stone (1926) for an early work advocating compulsory insurance laws on this basis). When drivers have limited assets, such laws also force drivers to at least partly internalize some of the externality imposed on others by their driving (Shavell (1987), Keeton and Kwerel (1984)).

Compulsory insurance regulation was first introduced in Massachusetts in 1927. It had been adopted by 22 states by 1975, and by 45 states by 1997, the end of the sample period (see Table 2). Among these states, there is variation in the amount of each type of insurance that individuals are required to purchase and in the methods used to enforce this regulation. We observe two aspects of enforcement: 40 states require that a driver's insurance status be reported at the time of an accident, and 35 states require that insurance companies notify the appropriate state authorities if a driver's insurance policy lapses.

\subsection{Accident Liability Systems: Tort vs. No-Fault}

Historically the liability of drivers for accident losses was governed by tort principles. Drivers were liable for losses to others that resulted from their negligent behavior. In theory, a tort system with a negligence rule that functions perfectly - i.e., in which courts can always costlessly and accurately determine whether behavior was negligent - provides optimal incentives for care in driving and accident prevention. However, in practice, the tort system has various flaws, such as the substantial administrative costs and delays involved in adjudicating negligence and thus liability.

Perceived problems with the tort system have led reformers to propose no-fault liability systems. As early as 1926, there was analysis of the idea that there are potential benefits from limiting negligence-based suits and offering protection against injuries in automobile insurance regardless of fault (see Sherman (1926)). In 1932, the Columbia University Counsel for Research in Social Sciences proposed a scheme in which each motor vehicle owner would be required to carry a policy covering him against liability arising from 
injury, economic loss, or death, regardless of fault. In 1965, Keeton and O'Connell (1965) published an influential study calling for a move to a no-fault system.

The first jurisdiction to adopt such a scheme was Saskatchewan (in Canada) in 1946. In the US, the first state to adopt a no-fault system was Massachusetts in 1971. By 1975, 16 states had adopted a no-fault system. Most of these states (with the exception of Massachusetts and New York) adopted compulsory insurance concurrently with no-fault limitations on liability. The number of states with a no-fault system fell to 14 in 1997, with 6 states switching status in between.

There are two important elements of a no-fault system. First, (most) no-fault systems require drivers to purchase insurance that provides first-party coverage for accident losses, regardless of who was at fault. Second, no-fault systems limit the extent to which drivers can be sued through negligence-based suits. In a pure no-fault system, victims do not have any recourse to negligence-based suits. However, all states provide for thresholds beyond which the parties to an accident have recourse to lawsuits. As outlined in Table 2, in 13 states (Arizona, the District of Columbia, Delaware, Maryland, New Hampshire, Oregon, Pennsylvania, South Carolina, South Dakota, Texas, Virginia, Washington, and Wisconsin) no-fault exists in parallel with the traditional tort system. In these so-called add-on states, there are no limitations to litigation. The remaining states provide either a monetary or verbal (i.e., descriptive) threshold beyond which individuals have the right to sue.

Add-on regulations are a combination of the no-fault and tort systems, adding no-fault protection to the tort system without imposing any limitations on the latter. Ten states adopted add-on regulations. Because of its hybrid nature, it is difficult to predict the effects of add-on regulation. Hence, we focus on no-fault, but will examine the effect of the threshold below which tort limitations are imposed.

\section{Theoretical Predictions and Testing Approach}

We begin by discussing the effect of compulsory insurance laws on uninsured motorists and fatalities, both theoretically and empirically. Next, we discuss the effect of no-fault laws on fatalities and uninsured motorists, and the issues that arise in identifying the effect of no-fault laws as distinct from compulsory insurance laws. Finally, we discuss the direct effect of 
uninsured motorists on traffic fatalities and the instrumental variables identification of this effect.

\subsection{The Effect of Compulsory Insurance Regulations}

The effects of compulsory insurance regulation on drivers will vary depending on what insurance choice they would have made in the absence of compulsory insurance. Figure 1 identifies four groups of individuals.

Figure 1: Insurance Status before and after Compulsory Insurance

\begin{tabular}{llll}
\hline \hline & \multicolumn{2}{l}{ Status with compulsory insurance } \\
\cline { 3 - 3 } & & Insured & Uninsured \\
Status & Insured & (Insured, Insured) & (Insured, Uninsured) \\
without & & \\
$\begin{array}{l}\text { compulsory } \\
\text { regulation }\end{array}$ & Uninsured & (Uninsured, Insured) & (Uninsured, \\
\hline
\end{tabular}

The individuals in the $(1,1)$ cell would have purchased insurance in the absence of regulation, and continue to do so when it is compulsory. For these "always-insurers", the regulation has no direct effect, since their insurance status does not change (we adapt the terminology of Imbens and Angrist (1992)). ${ }^{4}$

Drivers in the $(2,1)$ cell are induced to adopt insurance because of compulsory insurance regulation. This is the group for whom the instrumental variables method identifies the effect of insurance on fatalities. These individuals did not deem insurance to be worthwhile or necessary in the absence of regulation, but they obtain it when it is compulsory. These drivers are forced to pay the premium, but accordingly are faced with

\footnotetext{
${ }^{4}$ It can, however, have indirect effects, through the price of insurance and through the insurance status of other drivers. However these indirect effects are either negligible or second-order. This would influence individual's decisions regarding how much insurance to purchase. Another indirect effect would be with respect to liability from, or to, other drivers involved in an accident. If drivers are insured, in principle they are covered regardless of the insurance status of the other driver. Of course the insurance company is affected, and this may have an indirect
} 
diminished liability in case of an accident. Because of the classic moral-hazard problem (see Shavell $(1979,1982))$, these individuals typically will drive less carefully when insured. ${ }^{5}$

Individuals in the $(2,2)$ cell would not have purchased insurance in the absence of regulation, and do not purchase it even when it is compulsory. The driving behavior of these individuals is affected to the extent that compulsory insurance laws succeed in inducing some individuals to switch from being uninsured to being insured. To the extent that compulsory insurance laws are effective, those drivers who remain uninsured are induced to drive more carefully, since their status as uninsured drivers is illegal under compulsory insurance laws. If, however, compulsory insurance laws were ineffective and did not induce drivers to switch into insurance, then there would be no effect on uninsured drivers. We expect that the former case is empirically relevant.

Finally drivers in the $(1,2)$ cells would be insured in the absence of compulsory insurance, but choose not to insure themselves when it is required. Assuming that individuals do not derive some benefit from defying compulsory insurance regulations, this cell will be empty.

In summary, we have identified two critical groups: those who adopt insurance because of regulation (who are likely to drive more and less carefully) and those who are always uninsured (who are likely to drive less and more carefully because of regulation).

Hypothesis H1: Under compulsory insurance:

(i) The proportion of uninsured motorists decreases.

(ii) The decrease in uninsured motorists produces an increase in fatalities among switchers.

(iii) Those who remain uninsured motorists drive more carefully, producing a decrease in fatalities for this group.

effect on the insured driver through the price of insurance. These indirect effects presumably have only a small impact on driving behavior, since this is more likely to be affected by insurance status than the extent of coverage.

${ }^{5}$ Shavell (1982) notes that the presence of insurance creates equivalence between strict liability and a negligence rule form of liability. Though insurance does create moral hazard, Shavell demonstrates that the provision of insurance is socially desirable. 
We test these hypotheses by examining the direct effect of compulsory insurance laws on fatalities and uninsured motorists. An issue that arises in identifying the effects of compulsory as distinct from no-fault regulations is that both sets of laws often were introduced together. In particular, states that adopted no-fault limitations on liability adopted compulsory insurance regulations at the same time, and likewise for add-on regulations. As a result, to identify the effect of compulsory insurance, we restrict attention to states and years that have neither no-fault nor add-on provisions. We refer to this as the compulsory sample. Table 3, column (1), presents the states and years that are included in this sample. All 50 states and regions are represented in the sample. In the Midwestern, Southern, and Western states, approximately half are present for the entire sample period. The least represented region is the Northeast, with New Hampshire, Rhode Island, and Vermont represented for the full sample period, but many other Northeastern states represented only in the early 1970s.

\subsection{The Effect of No-Fault Systems}

The literature on no-fault systems has argued that motorists will drive less carefully under no-fault than a tort system. Since a no-fault system limits drivers' liability from their actions, it weakens their incentives to take precautions when driving. By the same token, it also could lead to increased driving.

However, this argument ignores the fact that the effects of no-fault limitations on liability will be different for insured and uninsured drivers. The standard analysis applies to the former group. Insured drivers are protected (by insurance) from liability if they are the victims of an accident, and no-fault limits their liability if they cause an accident. In contrast,

for uninsured drivers the incentives differ in these two cases. If an uninsured driver causes an accident, then he faces reduced liability under a no-fault scheme; this presumably leads to reduced precautions when driving. If an uninsured driver is the victim of an accident, his recourse to compensation is also limited in a no-fault system; this would lead to more cautious driving behavior. These two effects go in opposite directions, as summarized in the following hypothesis. 
Hypothesis H2: By adopting no-fault limitations on liability in addition to compulsory insurance requirements:

(i) For uninsured drivers, coverage decreases, possibly leading to a decrease in fatalities.

(ii) For insured drivers, liability decreases, leading to an increase in fatalities.

The overall effect is thus theoretically ambiguous, and an empirical investigation is needed.

As discussed above, one difficulty with identifying the effect of no-fault laws as distinct from compulsory laws is that most states adopted these laws at the same time. To identify the effect of no-fault limitations on liability, as distinct from compulsory insurance, we examine the effect of no-fault among states that have either compulsory insurance or nofault regulation, excluding add-on states (we call this the no-fault sample). As we can see from column (2) of Table 3, this is a somewhat more restrictive sample. All regions are represented, but for a reduced period. Many states are present later in the sample period after they had adopted compulsory, no-fault and compulsory, or had eliminated no-fault or add-on provisions.

We cannot (and do not) claim that this sample, and likewise the compulsory sample discussed in Section 3.1, corresponds to the full sample of U.S. states. However, both samples are broadly representative. Further, we will allow for year fixed effects to address the issue that the no-fault sample is more representative of the latter half of the sample period. Finally, the samples represent the only sub-groups in which the effects of these policies can be identified, so to that extent we have to accept this limitation.

\subsection{The Effect of Insurance Status on Fatalities}

To the extent that insurers cannot monitor the behavior of the policyholder perfectly and make the policy conditional on optimal behavior, insurance coverage will tend to reduce the care and precautions that drivers take while driving. This is the familiar moral hazard cost of insurance. Thus, the prediction is that the higher the proportion of uninsured motorists, the lower the number of accidents. 
Hypothesis H3: A higher incidence of uninsured motorists leads to fewer traffic fatalities.

In the popular press and in the literature on uninsured motorists, the existence of such motorists is viewed as unambiguously bad. We do not question that the presence of automobile insurance produces risk-bearing and compensation benefits. Our interest, however, is in exploring whether insurance also has a down side, a moral hazard cost, which needs to be taken into account in any assessment of uninsured motorists and regulations affecting their incidence.

We use an instrumental variable strategy to identify the effect of uninsured motorists on traffic fatalities; because both of these outcomes are jointly determined, OLS estimation of the relationship would be subject to simultaneity bias. ${ }^{6}$ As established in Imbens and Angrist (1992) and Angrist, Imbens, and Rubin (1994), an instrumental variables strategy identifies the effect of the instrument on those who are induced to change their "treatment assignment" based on the instrument. In our case, the instrumental variables strategy thus identifies the effect on those induced to join insurance as a result of compulsory insurance regulation. As discussed in Section 3.1, we expect the effect for this group to be negative: as the proportion of uninsured motorists decreases, fatalities increase because of the moral hazard effect on switchers.

The two candidates for instrumental variables are compulsory insurance and no-fault liability laws. In Section 5.1 we argue that both sets of laws are exogenous conditional on a range of controls, hence plausible candidates for instruments. But we must also consider whether either of these variables satisfies the requirement that they affect the outcome (fatalities) only through their effect on uninsured motorists.

As discussed in Section 3.2, no-fault laws affect fatalities by influencing the liability that drivers face from their actions. Even if the number of uninsured motorists were unaffected by no-fault laws, the laws could have a significant effect on fatalities through incentive effects on both motorists who are currently insured and those who are uninsured.

\footnotetext{
${ }^{6}$ In particular, traffic fatalities depend on the number of insured drivers, but we can imagine a second equation in which drivers choose insurance status based on the rate of traffic fatalities. In this case, the OLS estimates of a single equation will be inconsistent.
} 
Instead, the direct effect of the adoption of compulsory insurance on fatalities is to induce motorists to switch from being uninsured to insured. There is also potentially an indirect effect, namely inducing drivers who remain uninsured to drive more carefully. Despite the possibility of an indirect effect, we believe that an instrumental variable is a reasonable strategy for two reasons. First to the extent that the indirect effect depends on the number of uninsured motorists induced to drive more safely, the effect should be small. Second, and more importantly, to the extent that the indirect effect of compulsory insurance on fatalities will lead to a reduction in traffic fatalities (if uninsured motorists are induced to drive more safely), any direct positive effect we find must be downward biased relative to the true effect. ${ }^{7}$

\section{Data Description}

We use a panel of annual state-level variables. The data cover all 50 U.S. states and the District of Columbia for the years 1970-1998. ${ }^{8}$ The data include information about (1) some components of automobile insurance law; (2) the level of uninsured motorists; (3) states' demographics characteristics; and (4) fatality rates.

We obtain information about automobile insurance regulations and accident liability regulations from the American Insurance Association (AIA) for the years 1970 to 2001. The variables we use are: (1) whether a state has compulsory auto insurance - "yes" denotes those states requiring minimum liability insurance or showing some proof of financial responsibility; (2) which enforcement mechanisms a state uses for compulsory insurance (including checking insurance status at the time of an accident, or verifying insurance status at the time of vehicle registration); (3) whether a state adopted a no-fault or add-on system instead of a tort liability system (the default), and (4) whether a no-fault state has a monetary or verbal threshold (and the value of the threshold).

We obtain data on uninsured motorists from the Insurance Research Council (IRC) for the years 1976-1998. Several methods have been used to estimate the proportion of uninsured motorists; see Khazoom (1997). From these, we use the IRC's estimates, because

\footnotetext{
${ }^{7}$ Thus, if the direct effect of uninsured on fatalities is negative, an indirect effect would bias our results toward zero.
} 
they are the most comprehensive of those available. ${ }^{9}$ The incidence rates of uninsured motorists reported by the IRC vary considerably across states, from $4 \%$ in Maine to $30 \%$ in Colorado and South Carolina (for the year 1997).

A description of our variables appears in Table 1, and their sources are outlined in the Data Appendix.

\section{The Results}

\subsection{The Conditional Exogeneity of the Laws}

In studying the effect of compulsory insurance and no-fault regulation on the proportion of uninsured motorists and driving fatalities, it is important to investigate first whether the laws are plausibly exogenous (conditional on the covariates and time and year fixed effects in our specification). The concern is a systematic selection of which states choose to adopt these laws and when. There are three potential sources of selection.

First is selection on observables: states that choose to adopt may differ in terms of age, population, ethnicity, and income. We will address this by including these variables as controls in our subsequent specifications. Second, we are concerned with selection on the outcome, in particular that states with a higher level of uninsured motorists or fatalities may be more likely to enact automobile insurance legislation. This will be addressed by allowing for state and year fixed effects. Third, there could be time-varying selection on the outcome. In particular, states that experience a shock (for example a sudden increase) in one of the outcomes may be more likely to adopt regulation. Since controlling for lagged dependent variables in a fixed-effects regression is challenging, this is a greater concern.

\footnotetext{
${ }^{8}$ Information on uninsured motorist is available only from 1976 on.

${ }^{9}$ The IRC uses two variables to calculate the proportion of uninsured motorists: Uninsured Motorists Claim, which is the number of uninsured motorists claims for injuries caused to the insured by uninsured motorists and Bodily Injury Liability Claim (BI), which is the number of injuries caused by insured motorists. The ratio of Uninsured Motorists Claim frequency to Bodily Injury Liability Claim frequency is then used to measure the extent of the uninsured motorist problem. Under the null hypothesis of no moral hazard and equal probability of an accident for insured and uninsured motorists, it can be shown (using the model of Levitt and Porter (2001)) that the IRC measure is identical to the fraction of uninsured motorists in the population. Thus, this issue does undermine our conclusion that the possibility of no moral hazard can be rejected. Furthermore, as an empirical matter, we check the robustness of our results to using the $\log$ (rather than the level) of uninsured, since this variable is more robust to potential measurement error.
} 
Table 4 examines selection issues empirically. In columns (1) and (4) we present a probit regression of compulsory insurance and no-fault regulation on a range of exogenous variables, including population, ethnic composition, crime, per capita income, and the age profile of the population. Most are statistically significant predictors of the laws. States with a lower proportion of blacks, more violent crimes, and a higher proportion of drivers outside the 18-to-24 age range are more likely to have compulsory insurance. For no-fault, the signs are largely reversed. This basic set of variables predicts the laws with about 70 percent accuracy. Thus, in our subsequent specifications, controlling for these observables will account for a significant proportion of selection into the laws. Of course, we will also include an additional, powerful source of control, namely state and year fixed effects.

In columns (2) and (3) we examine the predictive power of lagged differences in the proportion of uninsured motorists and fatalities for compulsory insurance, and in columns (5) and (6) we examine the impact of these variables on no-fault. Neither the first nor the second set of lagged differences is a significant predictor of compulsory insurance or no-fault regulation. Furthermore, the increase in the predictive power of the models is minimal, increasing from 68 to 72 percent for compulsory and 77 to 78 percent for no-fault regulation. This suggests that shocks to outcomes are not a significant source of selection in our data.

Of course it is impossible to rule out the possibility of forward-looking selection on outcomes. But the evidence we examine suggests that our exogenous controls and state and year fixed effects address the most important issues of selection.

\subsection{The Effect of Compulsory Insurance}

We begin by examining the impact of compulsory insurance laws on the proportion of uninsured motorists and traffic fatalities. In addition to being of intrinsic interest, this will serve as the first stage of our instrumental variables strategy, presented in the next section. As indicated above, compulsory insurance was introduced by some states concurrently with no-fault. In order to obtain an estimate of the effect of compulsory insurance, unconfounded with the effects of no-fault, we restrict ourselves to the sample of states and years that were not under a no-fault or add-on regime. 
Table 5 presents our specifications. In addition to introducing a dummy for compulsory insurance, we control for a range of variables including automobile registration per capita, proportion of trucks among registered vehicles, the fraction black of the population, violent and property crimes, unemployment, and per capita real income. In column (1) we see that the direct effect compulsory is negative and statistically significant at the one percent level. This confirms hypothesis H1(i). The magnitude is large as well. Compared to a base level of 12.9 percent, compulsory insurance reduces uninsured motorists by 2.4 percentage points.

The result in column (1) is important for two reasons. First, it establishes that compulsory insurance achieved at least part of its mandate of reducing uninsured motorists. Second, the size and significance of the effect will be helpful when using compulsory insurance as an instrument for uninsured motorists.

In columns (2) and (3), we examine the robustness of this result. In column (2) we see the effect of compulsory insurance within a four-year window of the passage of compulsory insurance laws. Though this more than halves the number of observations, using a narrower window reduces the effect that state-specific time trends might have on the estimates. We note that the effect remains similar in sign, magnitude, and significance. In column (3), we reestimate column (1) using $\log$ uninsured as the dependent variable. We find that compulsory insurance remains negative and significant at the 1 percent level and that the magnitude of the effect is very similar: the coefficient of -0.024 in column (1) corresponds roughly to a 20 percent effect on uninsured, as does the effect in column (3).

In column (4) we examine the impact of two mechanisms used to enforce compulsory insurance, namely checking insurance status at the time of an accident and requiring that insurance is verified when the vehicle is registered. The former does not have a statistically significant effect, but the latter is significant and negative, further reducing uninsured motorists by 1.7 percentage points.

In columns (5) to (7) we see that the effect of compulsory insurance on fatalities per person is somewhat equivocal. In column (5), the direct effect is negative, though not statistically significant. When we estimate the effect within a four-year window of the adoption of compulsory insurance, shown in column (6), we find a positive (and 
insignificant) effect. In column (7), we see that when we include enforcement mechanisms for compulsory insurance (checking insurance status at the time of an accident, verifying insurance status at the time of registration) the direct effect is positive and significant, but the enforcement mechanisms have a negative (and significant) effect on fatalities.

The fact that the effect on fatalities is not overwhelming is not surprising in light of the discussion in Section 3.1 (hypothesis H1, ii and iii). Whereas individuals who switch from being uninsured to insured might drive less carefully, thereby increasing fatalities, we would expect the opposite effect for those individuals who remain uninsured.

\subsection{The Effect of Uninsured Motorists}

Table 6, column (1), presents an OLS regression of the effect of the ratio of uninsured motorists on fatalities per person. The coefficient is positive, but not statistically significant. However, as discussed above, this estimate potentially suffers from simultaneity bias. In subsequent columns, we address this issue by using an instrumental variables strategy.

Column (2) presents the estimated effect of uninsured on fatalities using compulsory insurance as an instrumental variable. We see that effect is negative and significant at the 5 percent level. This confirms hypothesis H3. The magnitude of the effect is such that a 0.01 increase in the ratio of uninsured motorists leads to a 2 percent decrease in fatalities per year (26 fatalities relative to a per state and year average on the order of 1000). A one standard deviation variation in uninsured would lead to a 10 percent decrease in fatalities. ${ }^{10}$

In columns (3) and (4) we examine the sensitivity of our results. When we estimate the effect in a four-year window of the passage of compulsory insurance regulations, we still obtain a negative estimate. The fact that the coefficient is no longer significant is not surprising given that we lose two thirds of our observations, and of course still allow for state and year fixed effects. In column (4) we examine the impact on log uninsured. The effect has

\footnotetext{
${ }^{10}$ The reason why we estimate the effect of uninsured on fatalities for the compulsory sample is that our instrumental variables strategy is valid only for this sample. For compulsory insurance we have a clear case that any direct effect of compulsory on fatalities will bias our results toward zero. Instead, in the full sample we have to contend with the direct and indirect effects of no-fault regulation (since these cannot be distinguished from the effect of compulsory insurance, in the full sample). In particular, though the effect of no-fault regulation through uninsured may lead to a decrease in fatalities, the direct effect of no-fault leads to an increase in fatalities, as we show in Section 5.4.
} 
the same sign, and remains statistically significant at a 1 percent level. The magnitude of the effect is also similar.

In columns (5) and (6) we examine the robustness of the result to additional controls. In column (5) we control for vehicle miles traveled per person. This controls for shifts in driving patterns that might account for changing fatalities. In principle, vehicle miles traveled should also be seen as an outcome, since it can be influenced by insurance regulation. The magnitude of the coefficient on uninsured motorists increases, and remains statistically significant. In column (6) we control for an additional range of variables (automobile registration per person, average speed, alcohol consumption per capita, and the proportion of new cars), and again the effect of interest remains statistically significant. ${ }^{11}$

Hence the negative relationship between the proportion of uninsured motorists and traffic fatalities confirms the moral hazard effect discussed in Section 3.1. Because instrumental variables identify the effect experienced by those induced to switch as a result of compulsory insurance, the instrumental variables estimate identifies the effects on switchers, and confirms the moral hazard story. ${ }^{12}$

It is important to stress that the purchase of insurance by motorists has effects other than on fatalities, and these effects are clearly beneficial. Such insurance reduces the riskbearing costs of drivers and leads to compensation of some victims who otherwise would receive less or no compensation. So, although interesting and important for its own sake, the moral hazard costs of insurance are just one element in an overall evaluation of the incidence of uninsured motorists.

\footnotetext{
${ }^{11}$ We use fatalities per person, rather than fatalities per vehicle mile traveled (which is more common in the literature), as the outcome because vehicle miles traveled is potentially affected by changes in regulation, rendering the latter more difficult to interpret. Our results are similar when using fatalities per vehicle mile traveled.

${ }^{12}$ As noted in Imbens and Angrist (1992), even though the IV estimator identifies the effect of the endogenous variable on the outcome for those induced to switch by the instrument, we cannot specifically identify these individuals in our data. To the extent that we think of uninsured drivers as being inherently riskier (in terms of risk attitude -- driving behavior, driving older vehicles, etc.) our result of increased fatalities among switchers makes sense.
} 


\subsection{The Effect of No-Fault Regulation}

As discussed in the introduction, the literature has established that no-fault laws increased traffic fatalities in conjunction with compulsory insurance. The literature has been confined to examining this joint effect because it has examined no-fault regulation in isolation from compulsory insurance. In this section, we identify the effect of no-fault, as distinct from compulsory insurance, by confining ourselves to the states and years that had either compulsory insurance or no-fault. Hence, the effect of no-fault is relative to the starting point of compulsory insurance. ${ }^{13}$

In Table 7, columns (1) to (5), we examine the effect on uninsured motorists. In column (1), we see that no-fault increases uninsured motorists: the effect is both large (3.1 percentage points) and significant (at the one percent level). In column (2) we reestimate the same specification in a four-year window of the passage of no-fault legislation. The effect is somewhat larger in magnitude, and still statistically significant. In column (3), we run the log specification and obtain similar results: the effect is significant at a 1 percent level and corresponds to a magnitude of roughly 3 percent. ${ }^{14}$

In column (4) we examine the effect of the thresholds above which accident victims can resort to tort claims. A no-fault system with a low threshold essentially should operate like a tort system, since most claims exceed the threshold beyond which tort action is permitted (a result which is established theoretically in Liao and White (1999)). A threshold of zero corresponds to an add-on system where victims have a choice of whether to resort to no-fault or tort. The lowest threshold among pure no-fault states is $\$ 200$. As the threshold increases, the no-fault system becomes more stringent. We incorporate this information into the categorical variable "level" which takes the value zero for add-on states, one for no-fault

\footnotetext{
${ }^{13}$ Note, however, that the form of compulsory insurance under tort and no-fault systems differs. Under tort, compulsory insurance consists of third-party coverage. Under no-fault, compulsory insurance consists of first-party coverage. We examine the sensitivity of our results to this difference as follows: we compare the effect of compulsory insurance under a tort system with the effect of a no-fault system with a low threshold. The latter system imposes only a negligible degree of tort limitation, and thus we estimate the effect of the move from third- to firstparty compulsory insurance. The effect is very small in magnitude, and not statistically significant. This suggests that our results are robust to this concern.
} 
states with low thresholds (less than \$200), and two for states with high thresholds (greater than \$500). If the effect of no-fault on uninsured motorists is robustly positive, then we expect this coefficient also to be positive: as the no-fault system becomes more stringent, uninsured motorists increase. Our results confirm this: the effect of the level variable is positive and significant. ${ }^{15}$ Of course, because the variable is categorical, the magnitude of the effect is difficult to interpret. ${ }^{16}$ Likewise in column (5) we note that the effect of level on log uninsured is positive and significant at a 1 percent level.

In columns (6) to (8) we examine the effect of no-fault on fatalities. In column (6) we see that the direct effect is positive and significant. Thus, from hypothesis H2, the effect of reduced liability dominates the effect of reduced insurance. The magnitude of the effect is on the order of 6 percent. This corresponds to 2,400 to 3,200 lives in the United States depending on the year. ${ }^{17}$ In column (7) we reestimate the effect in a four-year window of the passage of no-fault legislation. Since the sample size is greatly reduced, it is not surprising that the effect is no longer statistically significant. However, the sign of the effect remains positive, although the magnitude is smaller. In column (8) we observe that the threshold effect for fatalities is also positive and statistically significant. Overall, these results provide strong evidence of the incentive effects of no-fault regulation. In Section 3.3, we observed that, though drivers who are uninsured might in principle drive more carefully under nofault, insured drivers experience a reduction in their exposure to liability and would accordingly drive less carefully. Given the relative proportions of these two groups, it is natural that the latter effect dominates for fatalities. ${ }^{18}$

While the effect of no-fault on traffic fatalities is important, we wish to stress again that it is not the sole consideration in assessing such a system. Such a system has benefits in

\footnotetext{
${ }^{14}$ If we were to examine the effect of no-fault on uninsured in the full state-year sample the effect would be positive, but smaller in magnitude and not significant. This is because in the full sample the effects of no-fault and compulsory insurance are confounded (by the fact that they were typically introduced at the same time).

${ }^{15}$ Rolph, Hammitt, and Houchens (1985) using a micro-level cross-section of insurance claims in 1977, show that that a positive threshold leads to a reduction in bodily injury insurance claims. Our result differs because it allows for state and year fixed effects, covers a much longer time horizon, and examines the impact of the threshold on fatalities.

${ }^{16}$ An additional check would be to exclude low-threshold states from the no-fault group. Our results are robust to this specification.

${ }^{17}$ This is on the lower end of the range of estimates produced by Cummins, Phillips, and Weiss (2000).
} 
terms of reducing administrative costs, and these benefits might make it worthwhile even if it increases traffic fatalities. Whether this would be the case, of course, would depend on the magnitude of the effect, if any, on traffic fatalities.

\section{Conclusion}

This paper has investigated the effect of compulsory insurance regulation and no-fault limitations on the incidence of uninsured motorists and on traffic fatalities. Also, using compulsory insurance laws as an instrumental variable, we have investigated the effect of insurance on traffic fatalities.

The evidence indicates that compulsory insurance rules do deliver their intended effect, which is a significant reduction in the incidence of uninsured motorists. The evidence also indicates that increasing the incidence of insurance produces an increase in fatalities. The magnitude of this moral hazard effect is potentially large: a two percent increase in fatalities for each percentage point decrease in uninsured motorists. While the switch by some motorists to become insured increases fatalities, this is at least partly offset by the effect of compulsory insurance on those drivers who chose to remain uninsured. These individuals drive more carefully, which works to reduce fatalities. Finally, we have been able to isolate the effect of the reductions in liability brought about by moves to a no-fault system. Such reductions in liability produce a significant increase in fatalities. Our analysis indicates that drivers' behavior, like the behavior of economic agents in other contexts, is influenced by financial incentives. Reductions in the expected financial costs of accidents, produced by reductions in liability or by the purchase of liability insurance, lead to more traffic fatalities. ${ }^{19}$

It is interesting to note that the presence of uninsured motorists is generally regarded as a severe problem (see Insurance research Council (1999, 2000), National Association of Independent Insurers (1999), and Kahzoom (2000)). Assuming that it is undesirable to have

\footnotetext{
${ }^{18}$ In the full sample, the effect of no-fault on fatalities is smaller, though still statistically significant.

${ }^{19}$ Our results in this paper contrast with those of Cohen and Einav (2001). The latter study finds that mandatory seat belt laws are not associated with the moral hazard cost of increased fatalities. Whether this contrast in findings is due to differences in the type of payoff affected, or other institutional features of the laws, is an open question.
} 
uninsured motorists, researchers examining this subject have focused on ways to reduce the incidence of such motorists. We do not doubt that a reduction in the incidence of uninsured motorists will produce some benefits by increasing the extent to which accident victims are compensated. Indeed work by Grabowski, Viscusi, and Evans (1989) documents an increase in loss payments and a reduction in legal and administrative expenses under no-fault regimes. However, our analysis indicates that such reductions are not an unmitigated good. Automobile insurance also has a costly side, reducing precautions and increasing fatalities. ${ }^{20}$ Indeed, our work indicates that reducing the incidence of uninsured motorists might not make potential victims better off. To be sure, when some uninsured motorists switch to purchasing insurance, victims of accidents caused by these motorists might receive more compensation. However, potential victims also would face a higher incidence of such accidents. And, as long as victims cannot generally expect to be fully compensated for such accidents (which they cannot, as insurance levels are often insufficient to cover damages fully), increasing the number of accidents would be costly to potential victims. Whether or not potential victims would benefit from reducing the incidence of uninsured motorists thus would depend on which of these two effects is stronger, an issue which the present analysis cannot resolve.

Our analysis also indicates that, whatever the benefits of moving to no-fault liability, such benefits involve a significant moral hazard cost. In particular, the evidence suggests that such moves increase fatalities, and that this increase is larger than has been previously recognized.

Of course, our evidence does not enable us to reach an overall assessment of the rules governing accident liability and accident insurance. By focusing on traffic fatalities alone, we ignore, among other things, the effect of such rules on risk-bearing costs or on administrative costs. However, our analysis does highlight some of the unintended consequences of the rules governing automobile insurance and liability. By identifying and estimating the moral hazard costs of automobile insurance and no-fault arrangements, our analysis highlights important effects that should be taken into account in an overall assessment of these policies.

${ }^{20}$ In a full cost-benefit analysis, the value of the additional loss of life would have to be assessed. For details, see the 
extensive survey in Viscusi (1992), chapter 4. 


\section{References}

American Insurance Association (1976-2000), Summary of Selected State Laws and Regulations Relating to Automobile Insurance. New York: American Insurance Association.

Angrist, Joshua, Guido Imbens, and Donald Rubin (1994), "Identification of Causal Effects Using Instrumental Variables" (with discussion), Journal of the American Statistical Association, Vol. 91, pp. 444-72.

Cohen, Alma, and Liran Einav (2001), "The Effect of Mandatory Seat Belt Laws on Driving Behavior and Traffic Fatalities," Harvard Law School Olin Paper No. 341, forthcoming Review of Economics and Statistics.

Cole, Cassandra R., Randy E. Dumm, and Kathleen A. McCullough (2001), "The Uninsured Motorist Problem: An Investigation of the Impact of Enforcement and Penalty Severity on Compliance," Journal of Insurance Regulation, Vol. 19, pp. 613-637.

Cummins, J. David, Richard D. Phillips, and Mary A. Weiss (2001), "The Incentive Effects of No-Fault Automobile Insurance," Journal of Law and Economics, Vol. 44, pp. 427464.

Derrig, A. Richard, Maria Segui-Gomez, Ali Abtahi, and Ling-Ling Liu (2002), "The Effect of Population Safety Belt Usage Rates on Motor Vehicle-Related Fatalities," Accidents Analysis and Prevention, Vo. 34, pp. 101-110

Devlin, Rose Anne (1992), "Liability versus No-Fault Automobile Insurance Regimes: An Analysis of the Experience of Quebec," in George Dionne (ed.), Contributions to Insurance Economics. London: Kluwer Academic, pp. 499-520.

Dewees, Don, David Duff, and Michael Trebilcock (1996), Exploring the Domain of Accident Law. New York: Oxford University Press.

Edlin, Aaron (1999), "Per-Mile Premiums for Auto Insurance," National Bureau of Economic Research Working Paper No. 6934.

Edlin, Aaron and Pinar Karaca Mandic (1999), "The Accident Externality from Driving," unpublished.

Gaudry, Marc, "Measuring the Effects if the No-Fault 1978 Quebec Automobile Insurance Act with the Drag Model," in Contributions to Insurance Economics (G. Dionne, editor).

Grabowski, Henry, W. Kip Viscusi, and William Evans (1989), "Price and Availability Tradeoffs of Automobile Insurance Regulation," The Journal of Risk and Insurance, Vol. 56, pp. 275-299. 
Huberman, Gur, David Mayers, and Clifford W. Smith (1983), "Optimal Insurance Policy Indemnity Schedules", The Bell Journal of Economics, Vol. 14, 415-426.

Imbens, Guido, and Joshua Angrist (1992), "Identification and Estimation of Local Average Treatment Effects," Econometrica, Vol. 62, pp. 467-75.

Insurance Research Council (IRC) (1999-2000), Uninsured Motorists, Malvern, PA: Insurance Research Council.

Kahzoom, J. Daniel (2000a), "What We Know about Uninsured Motorists and How Well We Know What We Know," Journal of Insurance Regulation, Vol. 17, pp. 59-93.

Kahzoom, J. Daniel (2000b), "Pay-at-the-Pump: Automobile Insurance are view of Criticisms and Proposed Modifications," Journal of Insurance Regulation, Vol. 18, pp. 448-496.

Keeton, R. William, and Evan Kwerel (1984), "Externalities in Automobile Insurance and the Underinsured Driver Problem," Journal of Law and Economics, Vol. 27, pp. 149-179.

Kochanowski, S. Paul, and Madelyn V. Young (1985), "Deterrent Aspects of No-Fault Automobile Insurance: Some Empirical Findings," Journal of Risk and Insurance, Vol. 52(2), pp. 269-288.

Landes, M. Elisabeth (1982), "Insurance Liability and Accidents: A Theoretical and Empirical Investigation of the Effect of No-Fault Accidents," Journal of Law and Economics, Vol. 25, pp. 49-65.

Liao, Yu-Ping, and Michelle White (1999), "No-Fault for Motor Vehicles: An Economic Analysis," Department of Economics, University of Michigan, Working Paper No. 99016.

Levitt, Steven D. and Jack Porter (2001), “How Dangerous are Drinking Drivers?” Journal of Political Economy, Vol. 109, pp. 1198-1237.

Levitt, Steven D. and Jack Porter (1999), "Sample Selection in the estimation of Air Bag and Seat Belt Effectiveness," NBER Working Paper No. 7210.

Ma, Yu-Luen, and Joan T. Schmidt (2000), "Factors Affecting the Relative Incidence of Uninsured Motorists Claims," Journal of Risk and Insurance, Vol. 67, pp. 81-294.

McEwin, R. Ian (1989), "No-Fault and Road Accidents: Some Australasian Evidence," International Review of Law and Economics, Vol. 9(1), pp. 13-24 
Medoff, H. Marshall, and Joseph P. Magaddino (1982), “An Empirical Analysis of No-Fault Insurance," Evaluation Review, Vol. 6, pp. 373-392.

National Association of Independent Insurers (1999), The Ineffectiveness of Compulsory Private Passenger Automobile Liability Insurance laws.

Pauly, M. (1968), "The Economics of Moral Hazard: Comment," American Economic Review, Vol. 58, pp. 531-536.

Peltzman, Sam (1975), “The Effects of Automobile Safety Regulation,” Journal of Political Economy, Vol. 83, pp. 667-725.

Peltzman, Sam (1975), Regulation of Automobile Safety. Washington, DC: American Enterprise Institute.

Rolph, John, James Hammitt, and Robert Houchens (1985), "Automobile Accident Compensation: How Pays How Much How Soon?" Journal of Risk and Insurance, Vol. 52, pp. 667-685.

Ruhm, Christopher J. (1996), "Alcohol Policies and Highway Vehicle Fatalities," Journal of Health Economics, Vol. 15, pp. 435-454.

Sherman, P.T. (1926), "Compulsory Insurance of Compensation for Injuries by Automobile Accidents," Pamphlets on Insurance, Vol. 4, no. 7.

Shavell, Steven (1979), “On Moral Hazard and Insurance," Quarterly Journal of Economics, pp. 541-562.

Shavell, Steven (1982), "On Liability and Insurance," Bell Journal of Economics, Vol. 13, pp. $120-132$.

Shavell, Steven (1987), Economic Analysis of Accident Law. Cambridge, MA: Harvard University Press.

Shavell, Steven (2000), "On the Social Function and Regulation of Liability Insurance," Geneva Papers on Risk and Insurance, Vol. 25, pp. 166-179.

Sloan A. Frank, Reilly B.A., and Schenzler, C.M. (1994), "Tort Liability versus Other Approaches for Deterring Careless Driving," International Review of Law and Economics, Vol. 14, pp. 53-72.

Stone, Edward (1926), "Compulsory Automobile Liability Insurance," Pamphlets on Insurance, Vol. 4, No. 6. 
Spence, A. Michael and Richard Zeckhauser (1971), "Insurance, Information and Individual Action," American Economic Review, Vol. 61, pp. 380-387.

Viscusi, W. Kip (1992). Fatal Tradeoffs: Public and Private Responsibilities for Risk. New York, NY: Oxford University Press.

White, Michelle J. (1989), "An Empirical Test of the Comparative and Contributory Negligence Rules in Accident Law," RAND Journal of Economics, Vol. 20, pp. 308-330.

Winter, A. Ralph (2000), "Moral Hazard,“ in Handbook of Insurance (G. Dionne, editor). Boston, MA: Kluwer Academic.

Zador Paul, and Adrian Lund (1986) "Re-Analysis of the Effects of No-Fault Auto Insurance on Fatal Crashes," Journal of Risk and Insurance, 53, pp. 226-241. 
Data Appendix

\begin{tabular}{|c|c|}
\hline Variable & Description / Source \\
\hline Traffic fatalities & $\begin{array}{l}\text { Total of people being killed in a car accident. Years available: 1970- } \\
\text { 1975. Source: Highway Statistics; } 1975-1998 \text {. Source: the FARS. }\end{array}$ \\
\hline $\begin{array}{l}\text { Income per } \\
\text { capita }\end{array}$ & $\begin{array}{l}\text { Income per capita. Years available: 1976-1998. Source: 1976-1984, } \\
\text { Bureau of Economic Analysis. 1983-1998, U.S. Census. }\end{array}$ \\
\hline New cars & $\begin{array}{l}\text { Number of new cars registered. Years available: 1975-1998. Source: } \\
\text { Ward's Automotive Yearbook. }\end{array}$ \\
\hline $\begin{array}{l}\text { New cars per } \\
\text { registered }\end{array}$ & [New cars]/[registered] \\
\hline Population & $\begin{array}{l}\text { Total population. Years available: 1970-1998. Source: Bureau of } \\
\text { Justice Statistics. }\end{array}$ \\
\hline$\%$ Black & $\begin{array}{l}\text { Percentage Black of population. Extrapolated between non-census } \\
\text { years. Source: Statistical Abstract of the United States. }\end{array}$ \\
\hline$\%$ Hispanic & $\begin{array}{l}\text { Percentage Hispanic of population. Extrapolated between non-census } \\
\text { years. Source: Statistical Abstract of the United States. }\end{array}$ \\
\hline $\begin{array}{l}\% \text { Population } \\
\text { age } 5-17\end{array}$ & $\begin{array}{l}\text { The percentage of people in the population at the age } 5 \text { to } 17 \text {. Years } \\
\text { available } 1970-1998 \text {. Source: the U.S. Census. }\end{array}$ \\
\hline $\begin{array}{l}\% \text { Population } \\
\text { age } 18-24\end{array}$ & $\begin{array}{l}\text { The percentage of people in the population at the age } 18 \text { to } 24 \text {. Years } \\
\text { available } 1970-1998 \text {. Source: the U.S. Census. }\end{array}$ \\
\hline $\begin{array}{l}\% \text { Population } \\
\text { age } 25-44\end{array}$ & $\begin{array}{l}\text { The percentage of people in the population at the age } 25 \text { to } 44 \text {. Years } \\
\text { available 1970-1998. Source: the U.S. Census. }\end{array}$ \\
\hline $\begin{array}{l}\% \text { Population } \\
\text { age } 45-64\end{array}$ & $\begin{array}{l}\text { The percentage of people in the population at the age } 45 \text { to } 64 \text {. Years } \\
\text { available 1970-1998. Source: the U.S. Census. }\end{array}$ \\
\hline Property crimes & $\begin{array}{l}\text { Number of property crimes. Years available: 1970-1998. Source: } \\
\text { Bureau of Justice Statistics. }\end{array}$ \\
\hline $\begin{array}{l}\text { Property crimes } \\
\text { per capita }\end{array}$ & $\begin{array}{l}\text { Total property crime per capita. Years available: } 1970-1998 \text {. Source: } \\
\text { Bureau of Justice Statistics. }\end{array}$ \\
\hline Car registered & $\begin{array}{l}\text { Number of cars registered. Years available: 1976-1998. Source: } \\
\text { Ward's Automotive Yearbook. }\end{array}$ \\
\hline Trucks registered & $\begin{array}{l}\text { Number of trucks registered. Years available: 1975-1998. Source: } \\
\text { Ward's Automotive Yearbook. }\end{array}$ \\
\hline $\begin{array}{l}\text { Trucks, } \% \text { of } \\
\text { total registered }\end{array}$ & {$[$ Truck $] /([$ Truck $]+[$ Car Registered $]$} \\
\hline Average speed & Years available: 1975-1995 Source: Highway Statistics. \\
\hline $\begin{array}{l}\text { Unemployment } \\
\text { rate }\end{array}$ & $\begin{array}{l}\text { Unemployment rate. Years available: 1970-1998. Source: Bureau of } \\
\text { Labor Statistics. }\end{array}$ \\
\hline $\begin{array}{l}\text { Uninsured } \\
\text { motorists }\end{array}$ & $\begin{array}{l}\text { Number of claims when an insured motorist is injured by a motorist } \\
\text { who does not have liability insurance or by hit and run motorist. Years } \\
\text { available: 1976-1997 (missing } 1987 \text { and 1988). Source: the Insurance } \\
\text { Research Council }\end{array}$ \\
\hline Violent crime & $\begin{array}{l}\text { Number of violent crimes. Years available: 1970-1998. Source: } \\
\text { Bureau of Justice Statistics. }\end{array}$ \\
\hline $\begin{array}{l}\text { Violent crime } \\
\text { per capita }\end{array}$ & $\begin{array}{l}\text { Total violent crime per capita. Years available: 1970-1998. Source: } \\
\text { Bureau of Justice Statistics. }\end{array}$ \\
\hline $\begin{array}{l}\text { Vehicle miles } \\
\text { traveled, total }\end{array}$ & $\begin{array}{l}\text { Vehicle miles traveled for roads. Years available: } 1970-1998 \text {. Source: } \\
\text { Highway Statistics. }\end{array}$ \\
\hline
\end{tabular}


Table 1: Descriptive Statistics

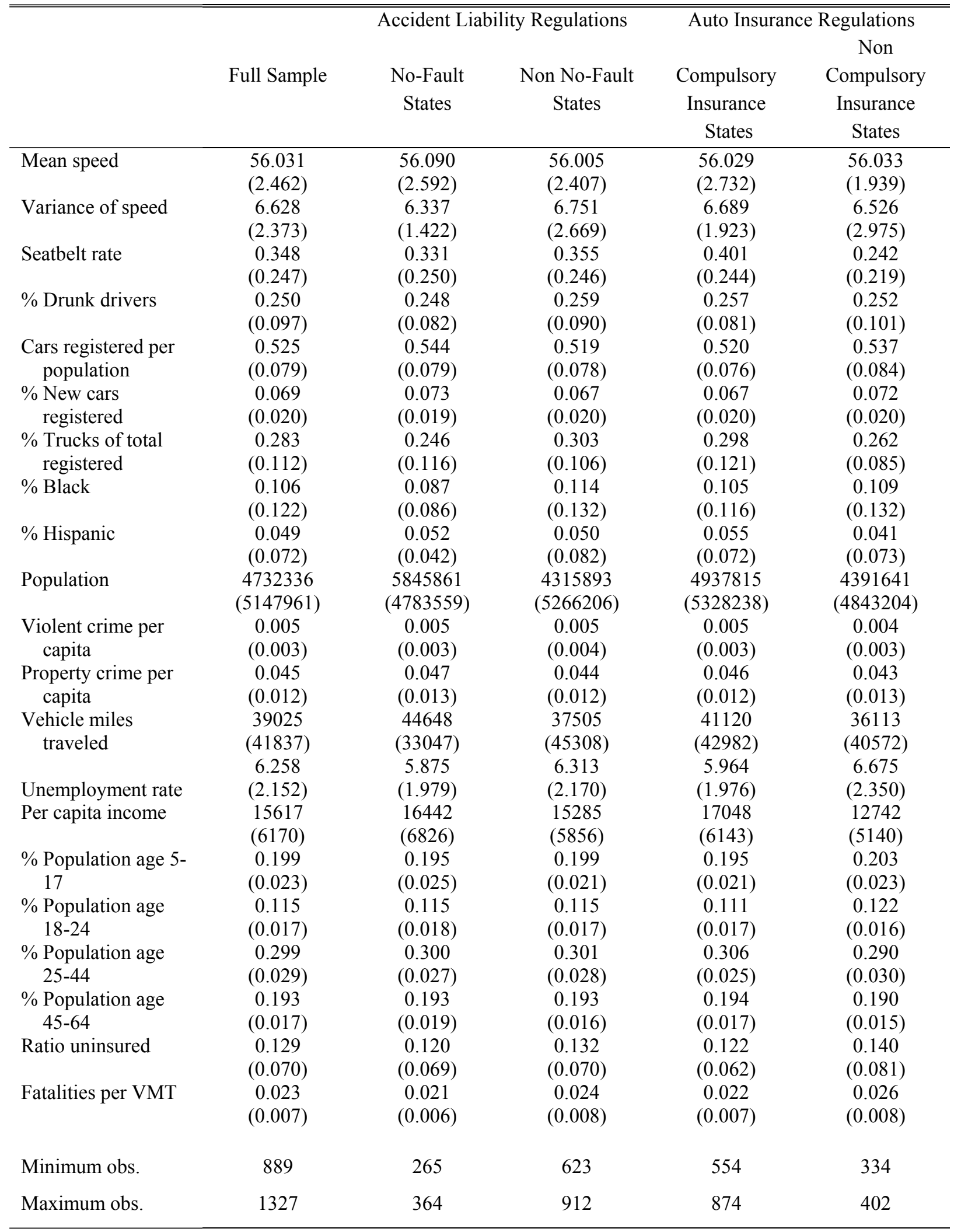




\begin{tabular}{|c|c|c|c|}
\hline State & Compulsory Insurance & No-fault Insurance & Add-on Provision \\
\hline Alabama & No & & \\
\hline Alaska & 1986- (except for year 1989) & & \\
\hline Arizona & 1983- (except for years 1990-1995) & & \\
\hline Arkansas & 1988- & & 1974- \\
\hline California & 1975- (except for years 1990-1995) & & \\
\hline Colorado & 1974- & $1974-$ & \\
\hline Connecticut & 1973- & 1973- & \\
\hline Delaware & 1972- & & $1972-$ \\
\hline District of Colombia & $1984-$ & 1984-1986 & $1987-$ \\
\hline Florida & 1972-1977 & 1972- & \\
\hline Georgia & $1975-$ & $1975-1991$ & \\
\hline Hawaii & 1974- & 1974- (except for year 1998) & \\
\hline Idaho & $1976-$ & & \\
\hline Illinois & 1989- & & \\
\hline Indiana & 1983- & & \\
\hline Iowa & $1998-$ & & \\
\hline Kansas & 1974- & $1974-$ & \\
\hline Kentucky & $1975-$ & $1975-$ & \\
\hline Louisiana & 1979 & & \\
\hline Maine & $1988-$ & & \\
\hline Maryland & 1973- & & 1973- \\
\hline Massachusetts & Before 1969- & 1971- & \\
\hline Michigan & 1973- & 1973- & \\
\hline Minnesota & $1975-$ & $1975-$ & \\
\hline Mississippi & No & & \\
\hline Missouri & 1987- & & \\
\hline Montana & $1981-$ & & \\
\hline Nebraska & 1986- & & \\
\hline Nevada & 1974- & 1974-1979 & \\
\hline New Hampshire & No & & 1971- \\
\hline New Jersey & $1973-$ & 1973- & \\
\hline New Mexico & $1984-$ & & \\
\hline New York & Before 1969 & $1974-$ & \\
\hline North Carolina & Before 1969 & & \\
\hline North Dakota & $1976-$ & 1976- & \\
\hline Ohio & $1984-$ & & \\
\hline Oklahoma & $1977-$ & & \\
\hline Oregon & $1980-$ & & 1972- \\
\hline Pennsylvania & $1975-$ & 1976-1983; 1990 - & 1984-1989 \\
\hline Rhode Island & 1992- & & \\
\hline South Carolina & $1974-$ & & 1974- (except for year 1990) \\
\hline South Dakota & $1987-$ & & $1972-$ \\
\hline \multicolumn{4}{|l|}{ Tennessee } \\
\hline Texas & 1984- & & $1973-$ \\
\hline Utah & 1974- (except for years 1990-1994) & $1974-$ & \\
\hline Vermont & $1986 ; 1988-1989 ; 1992-$ & & \\
\hline Virginia & $1984-$ & & 1972- \\
\hline Washington & 1991- & & $1978-$ \\
\hline West Virginia & 1986- & & \\
\hline Wisconsin & & & $1972-$ \\
\hline Wyoming & $1980-$ & & \\
\hline Number of states & 46 state & 17 states & 13 states \\
\hline
\end{tabular}


Table 3: Samples used for Compulsory and No-Fault

\begin{tabular}{|c|c|c|c|}
\hline State & Region & Compulsory evaluation sample & No-fault evaluation sample \\
\hline Iowa & Midwest & $1970-2000$ & $1998-2000$ \\
\hline Illinois & Midwest & $1970-2000$ & $1989-2000$ \\
\hline Indiana & Midwest & $1970-2000$ & $1983-2000$ \\
\hline Kansas & Midwest & $1970-1973$ & $1974-2000$ \\
\hline Michigan & Midwest & 1970-1972 & $1973-2000$ \\
\hline Minnesota & Midwest & $1970-1974$ & $1975-2000$ \\
\hline Missouri & Midwest & $1970-2000$ & $1987-2000$ \\
\hline North Dakota & Midwest & $1970-1975$ & $1976-2000$ \\
\hline Nebraska & Midwest & $1970-2000$ & $1986-2000$ \\
\hline Ohio & Midwest & $1970-2000$ & $1984-2000$ \\
\hline South Dakota & Midwest & 1970-1971 & \\
\hline Wisconsin & Midwest & 1970-1971 & \\
\hline Connecticut & Northeast & 1970-1972, 1999-2000 & $1973-2000$ \\
\hline District of Columbia & Northeast & $1970-1983$ & 1984-1986 \\
\hline Massachusetts & Northeast & $1970-1971$ & $1970-2000$ \\
\hline Maine & Northeast & $1970-2000$ & $1988-2000$ \\
\hline New Hampshire & Northeast & 1970 & \\
\hline New Jersey & Northeast & 1970-1972 & $1973-2000$ \\
\hline New York & Northeast & 1970-1973 & $1970-2000$ \\
\hline Pennsylvania & Northeast & $1970-1975$ & $1975-1983,1990-200$ \\
\hline Rhode Island & Northeast & $1970-2000$ & $1992-2000$ \\
\hline Vermont & Northeast & $1970-2000$ & $1986,1988-1989,1992-2000$ \\
\hline Alabama & South & $1970-2000$ & \\
\hline Arkansas & South & $1970-1973$ & \\
\hline Delaware & South & $1970-1971$ & \\
\hline Florida & South & 1970-1971 & 1972-1977 \\
\hline Georgia & South & 1970-1974, 1992-2000 & $1975-2000$ \\
\hline Kentucky & South & $1970-1974$ & $1975-2000$ \\
\hline Louisiana & South & $1970-2000$ & $1979-2000$ \\
\hline Maryland & South & 1970-1972 & \\
\hline Mississippi & South & $1970-2000$ & \\
\hline North Carolina & South & $1970-2000$ & $1970-2000$ \\
\hline Oklahoma & South & $1970-2000$ & $1977-2000$ \\
\hline South Carolina & South & $1970-1973$ & $1974-1989,1995-2000$ \\
\hline Tennessee & South & $1970-2000$ & \\
\hline Texas & South & $1970-1972$ & \\
\hline Virginia & South & $1970-1971$ & \\
\hline West Virginia & South & $1970-2000$ & $1986-2000$ \\
\hline Alaska & West & $1970-2000$ & $1985-2000$ \\
\hline Arizona & West & $1970-2000$ & $1983-1989,1996-2000$ \\
\hline California & West & $1970-2000$ & $1975-1989,1996-2000$ \\
\hline Colorado & West & $1970-1973$ & $1974-2000$ \\
\hline Hawaii & West & $1970-1973$ & $1974-2000$ \\
\hline Idaho & West & $1970-2000$ & $1976-2000$ \\
\hline Montana & West & $1970-2000$ & $1981-2000$ \\
\hline New Mexico & West & $1970-2000$ & $1984-2000$ \\
\hline Nevada & West & $1970-1973,1980-2000$ & $1974-2000$ \\
\hline Oregon & West & $1970-1971$ & \\
\hline Utah & West & $1970-1973$ & \\
\hline Washington & West & $1970-1977$ & \\
\hline Wyoming & West & $1970-2000$ & $1980-2000$ \\
\hline
\end{tabular}


Table 4: Are the Laws Predictable?

\begin{tabular}{|c|c|c|c|c|c|c|}
\hline Dependent variable: & $\begin{array}{c}(1) \\
\text { Compulsory } \\
\text { insurance }\end{array}$ & $\begin{array}{c}(2) \\
\text { Compulsory } \\
\text { insurance }\end{array}$ & $\begin{array}{c}(3) \\
\text { Compulsory } \\
\text { insurance }\end{array}$ & $\begin{array}{c}\text { (4) } \\
\text { No fault } \\
\text { insurance }\end{array}$ & $\begin{array}{c}\text { (5) } \\
\text { No fault } \\
\text { insurance }\end{array}$ & $\begin{array}{c}(6) \\
\text { No fault } \\
\text { insurance }\end{array}$ \\
\hline Percent unemployed & $\begin{array}{c}-0.022 * * * \\
(-0.008)\end{array}$ & $\begin{array}{c}-0.018^{* *} \\
(-0.009)\end{array}$ & $\begin{array}{l}-0.017^{*} \\
(-0.009)\end{array}$ & $\begin{array}{l}-0.006 \\
(-0.007)\end{array}$ & $\begin{array}{c}-0.011 \\
(-0.009)\end{array}$ & $\begin{array}{c}-0.009 \\
(-0.009)\end{array}$ \\
\hline $\begin{array}{l}\text { Fraction of Blacks in } \\
\text { population }\end{array}$ & $\begin{array}{r}-0.49 * * \\
(-0.22)\end{array}$ & $\begin{array}{r}-0.55^{* *} \\
(-0.25)\end{array}$ & $\begin{array}{l}-0.50^{*} \\
(-0.26)\end{array}$ & $\begin{array}{l}-0.30 \\
(-0.21)\end{array}$ & $\begin{array}{r}-0.53 * * \\
(-0.26)\end{array}$ & $\begin{array}{r}-0.56^{* *} \\
(-0.28)\end{array}$ \\
\hline $\begin{array}{l}\text { Fraction of Hispanics } \\
\text { in population }\end{array}$ & $\begin{array}{c}-0.14 \\
(-0.28)\end{array}$ & $\begin{array}{l}-0.068 \\
(-0.31)\end{array}$ & $\begin{array}{c}0.031 \\
(-0.33)\end{array}$ & $\begin{array}{c}-1.51 * * * \\
(-0.36)\end{array}$ & $\begin{array}{c}-1.66^{* * *} \\
(-0.41)\end{array}$ & $\begin{array}{c}-1.59 * * * \\
(-0.44)\end{array}$ \\
\hline Population & $\begin{array}{c}-1.38 \mathrm{e}-09 \\
(-3.35 \mathrm{e}-09)\end{array}$ & $\begin{array}{c}-4.58 \mathrm{e}-09 \\
(-3.80 \mathrm{e}-09)\end{array}$ & $\begin{array}{c}-4.90 \mathrm{e}-09 \\
(-3.99 \mathrm{e}-09)\end{array}$ & $\begin{array}{r}2.01 \mathrm{e}-08^{* * * *} \\
(-3.44 \mathrm{e}-09)\end{array}$ & $\begin{array}{c}2.27 \mathrm{e}-08^{* * *} \\
(-4.02 \mathrm{e}-09)\end{array}$ & $\begin{array}{r}2.17 \mathrm{e}-08 * * * \\
(-4.23 \mathrm{e}-09)\end{array}$ \\
\hline $\begin{array}{l}\text { Violent crimes per } \\
\text { thousand }\end{array}$ & $\begin{array}{l}24.0^{* *} \\
(-11.4)\end{array}$ & $\begin{array}{l}29.9 * * \\
(-12.9)\end{array}$ & $\begin{array}{l}28.4 * * \\
(-13.5)\end{array}$ & $\begin{array}{c}-34.0 * * * \\
(-10.5)\end{array}$ & $\begin{array}{c}-30.6^{* * *} \\
(-12.0)\end{array}$ & $\begin{array}{r}-29.3^{* *} \\
(-12.7)\end{array}$ \\
\hline $\begin{array}{l}\text { Property crimes per } \\
\text { thousand }\end{array}$ & $\begin{array}{c}1.94 \\
(-1.85)\end{array}$ & $\begin{array}{c}0.22 \\
(-2.15)\end{array}$ & $\begin{array}{c}0.036 \\
(-2.25)\end{array}$ & $\begin{array}{l}9.74 * * * \\
(-1.76)\end{array}$ & $\begin{array}{c}8.17 * * * \\
(-2.05)\end{array}$ & $\begin{array}{c}7.38^{* * *} \\
(-2.16)\end{array}$ \\
\hline Real per capita income & $\begin{array}{c}-0.002 \\
(-0.011)\end{array}$ & $\begin{array}{c}0.013 \\
(-0.013)\end{array}$ & $\begin{array}{c}0.022 \\
(-0.014)\end{array}$ & $\begin{array}{c}0.083 * * * \\
(-0.009)\end{array}$ & $\begin{array}{r}0.092 * * * \\
(-0.011)\end{array}$ & $\begin{array}{c}0.099 * * * \\
(-0.012)\end{array}$ \\
\hline $\begin{array}{l}\% \text { population between } \\
\text { ages } 5 \text { and } 17\end{array}$ & $\begin{array}{l}4.66^{* * *} \\
(-1.05)\end{array}$ & $\begin{array}{c}6.51 * * * \\
(-1.37)\end{array}$ & $\begin{array}{l}7.64 * * * \\
(-1.52)\end{array}$ & $\begin{array}{c}-4.15^{* * *} \\
(-0.95)\end{array}$ & $\begin{array}{c}-4.21 * * * \\
(-1.22)\end{array}$ & $\begin{array}{c}-3.89 * * * \\
(-1.35)\end{array}$ \\
\hline $\begin{array}{l}\% \text { population between } \\
\text { ages } 18 \text { and } 24\end{array}$ & $\begin{array}{c}-3.85^{* * *} \\
(-1.15)\end{array}$ & $\begin{array}{c}-3.43 * * * \\
(-1.27)\end{array}$ & $\begin{array}{r}-2.88^{* *} \\
(-1.34)\end{array}$ & $\begin{array}{l}1.13 \\
(-1.07)\end{array}$ & $\begin{array}{c}1.61 \\
(-1.23)\end{array}$ & $\begin{array}{c}1.88 \\
(-1.32)\end{array}$ \\
\hline $\begin{array}{l}\% \text { population between } \\
\text { ages } 25 \text { and } 44\end{array}$ & $\begin{array}{l}6.30^{* * *} \\
(-1.11)\end{array}$ & $\begin{array}{c}5.61 * * * \\
(-1.23)\end{array}$ & $\begin{array}{c}4.90 * * * \\
(-1.28)\end{array}$ & $\begin{array}{c}-6.85^{* * *} \\
(-1.00)\end{array}$ & $\begin{array}{c}-7.08^{* * *} \\
(-1.13)\end{array}$ & $\begin{array}{c}-7.47 * * * \\
(-1.19)\end{array}$ \\
\hline $\begin{array}{l}\% \text { population between } \\
\text { ages } 45 \text { and } 64\end{array}$ & $\begin{array}{l}7.24 * * * \\
(-1.48)\end{array}$ & $\begin{array}{r}7.62 * * * \\
(-1.68)\end{array}$ & $\begin{array}{c}7.87 * * * \\
(-1.78)\end{array}$ & $\begin{array}{c}-5.92 * * * \\
(-1.35)\end{array}$ & $\begin{array}{c}-6.77 * * * \\
(-1.52)\end{array}$ & $\begin{array}{c}-6.99 * * * \\
(-1.62)\end{array}$ \\
\hline $\begin{array}{l}\text { Lagged first difference } \\
\text { of ratio uninsured }\end{array}$ & & $\begin{array}{c}0.088 \\
(-0.31)\end{array}$ & $\begin{array}{c}0.21 \\
(-0.36)\end{array}$ & & $\begin{array}{c}-0.17 \\
(-0.35)\end{array}$ & $\begin{array}{c}-0.41 \\
(-0.34)\end{array}$ \\
\hline $\begin{array}{l}\text { Lagged fist difference } \\
\text { of fatalities }\end{array}$ & & $\begin{array}{c}0.51 \\
(-1.77)\end{array}$ & $\begin{array}{c}0.96 \\
(-2.02)\end{array}$ & & $\begin{array}{l}-1.18 \\
(-1.89)\end{array}$ & $\begin{array}{c}-0.87 \\
(-2.18)\end{array}$ \\
\hline $\begin{array}{l}\text { Twice Lagged first } \\
\text { difference of ratio } \\
\text { uninsured }\end{array}$ & & & $\begin{array}{c}0.16 \\
(-0.34)\end{array}$ & & & $\begin{array}{c}-0.57 \\
(-0.46)\end{array}$ \\
\hline $\begin{array}{l}\text { Twice lagged first } \\
\text { difference of fatalities }\end{array}$ & & & $\begin{array}{c}0.42 \\
(-2.03)\end{array}$ & & & $\begin{array}{c}-0.25 \\
(-2.17)\end{array}$ \\
\hline Observations & 1221 & 910 & 808 & 1221 & 910 & 808 \\
\hline Predictive accuracy & 0.68 & 0.70 & 0.72 & 0.77 & 0.78 & 0.78 \\
\hline Observations & 1221 & 910 & 808 & 1221 & 910 & 808 \\
\hline
\end{tabular}

Standard errors in parentheses 


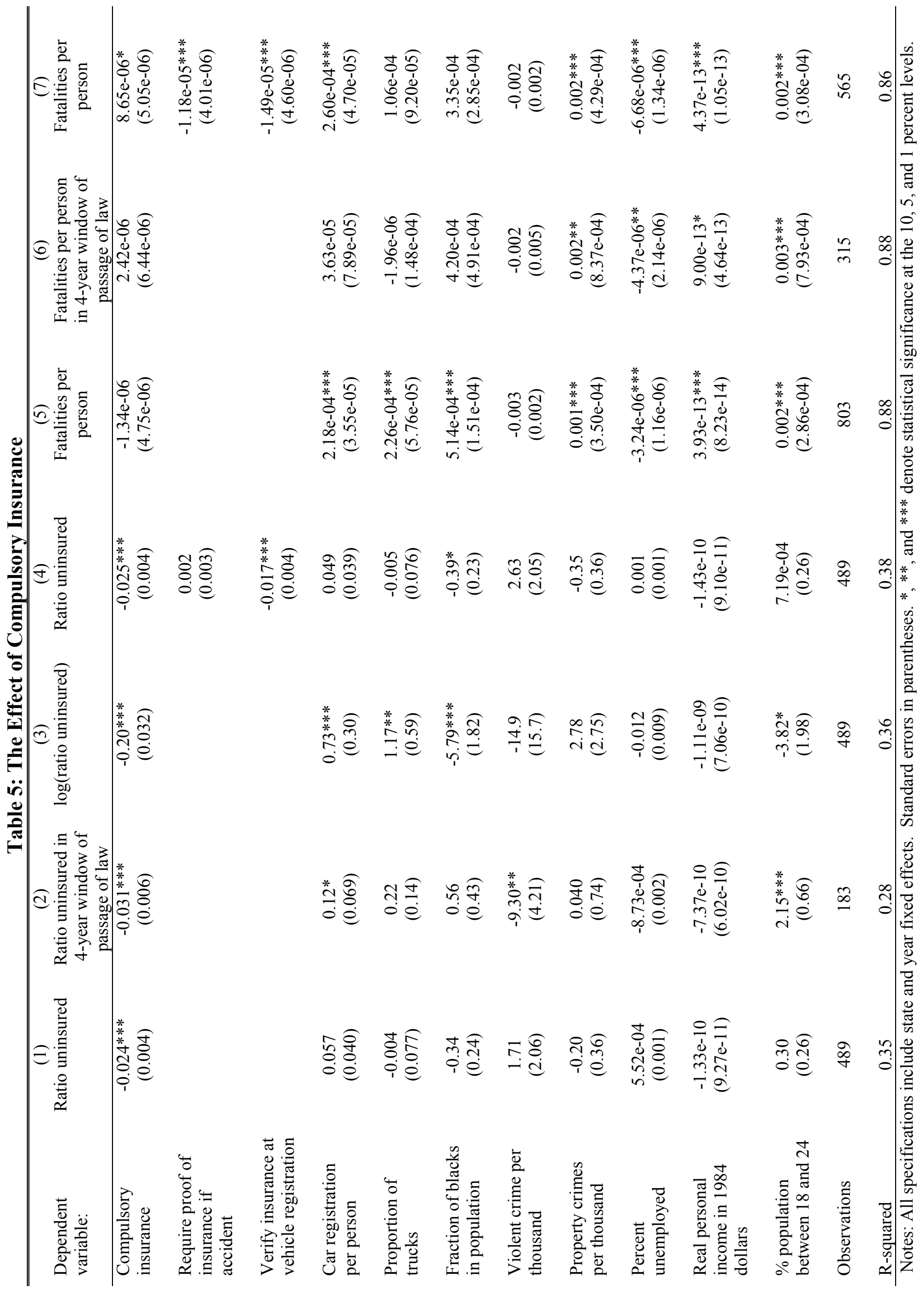




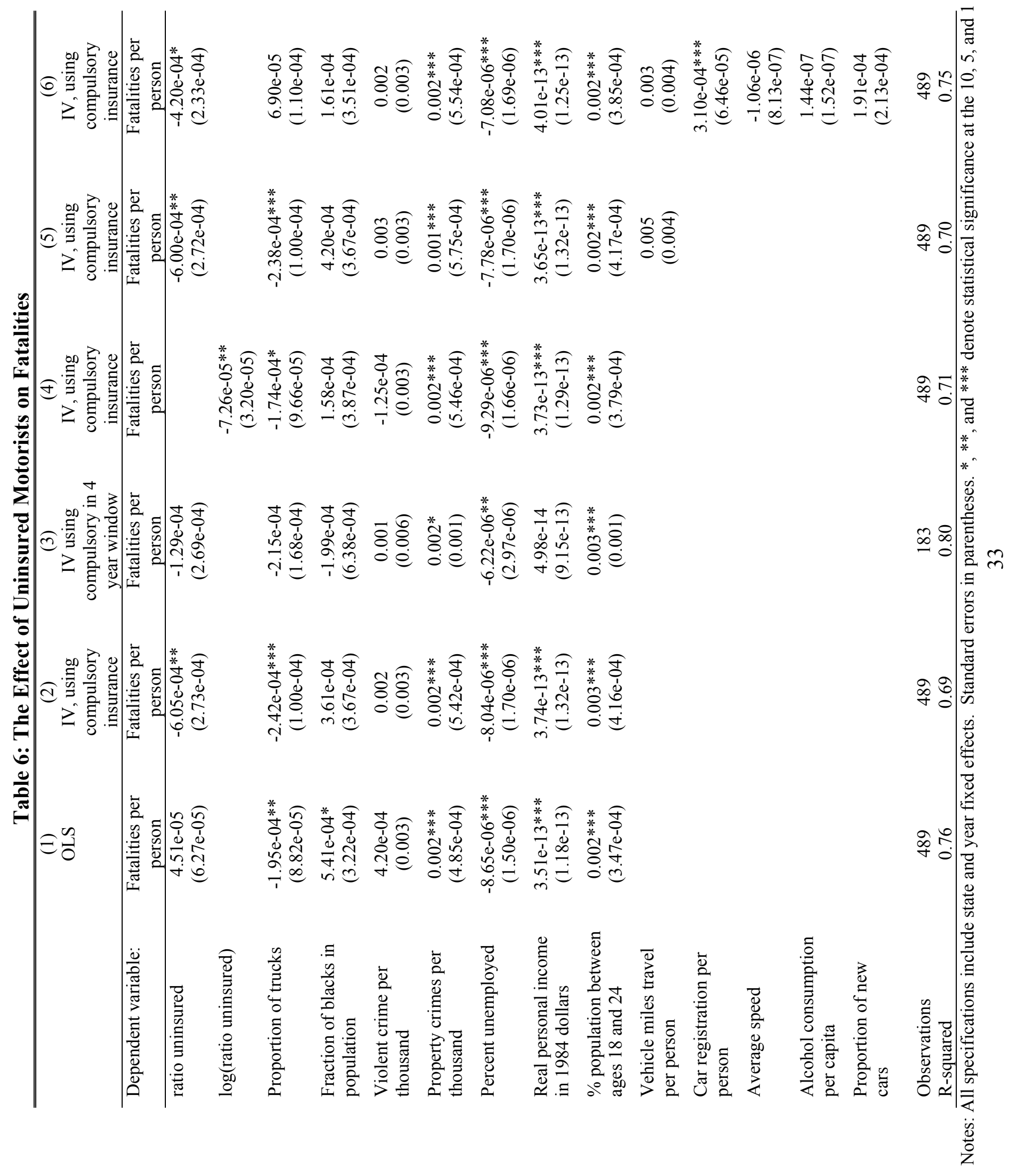




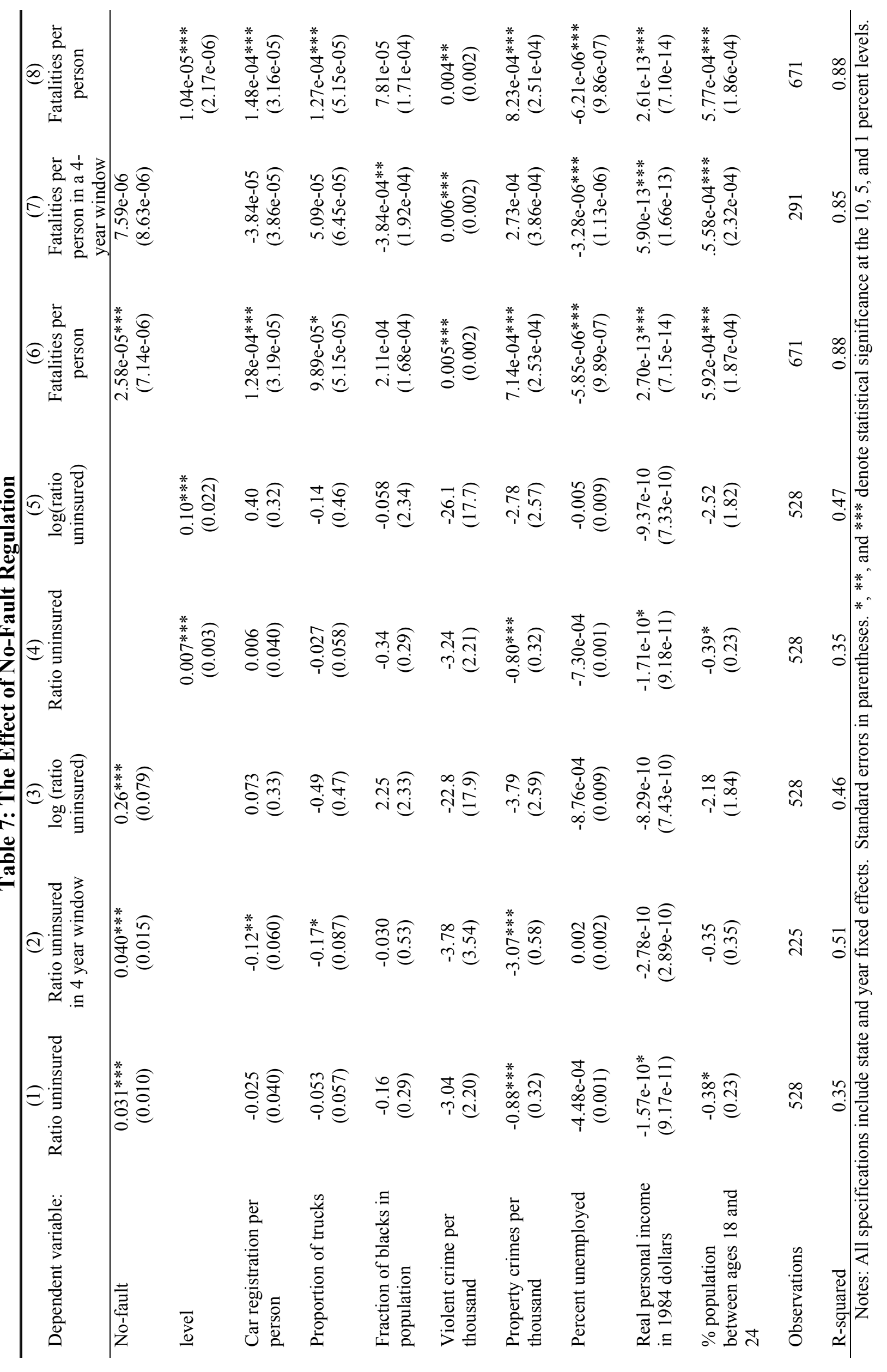

